уДК633.521:631.55

(C) 2013

Примаков О. А., кандидат технічних наук

Дослідна станція луб'яних культур Інституту сільського господарства Північного Сходу НААН

\title{
СИСТЕМНИЙ ПІДХІД У ДОСЛІДЖЕННІ ТЕХНОЛОГІЧНОГО ПРОЦЕСУ ЗБИРАННЯ ЛЬОНУ-ДОВГУНЦЯ
}

\section{Рецензент - доктор технічних наук Р. Н. Гілязетдінов}

\begin{abstract}
Розкривається питання обгрунтування раціональної схеми збирання льону-довгуния із застосуванням сільськогосподарських машин загального призначення. Проведено вибір необхідних та достатніх технологічних операцій для збирання льонудовгуния за новою технологією з аналізом кожного окремого елемента. При виборі технічних засобів для збирання льону акиент зроблено не на спеціальні льонозбиральні машини, а на техніку, що застосовується для збирання інших культур; ие робить технологію більш доступною для широкого кола сільгоспвиробників. На основі обгрунтування обраного комплексу технічних засобів складено первинну модель технологічної схеми збирання посіву льону-довгуния.
\end{abstract}

Ключові слова: льон-довгунецьь, технологія збирання, аналітичні дослідження, моделювання, технічні засоби.

Постановка проблеми. При аналізі й синтезі таких складних систем як механізовані процеси збирання, одержав розвиток системний підхід, який відрізняється від класичного (або індуктивного) підходу. Останній розглядає систему шляхом переходу від приватного до загального i синтезує (конструює) систему шляхом злиття ऑii компонентів, що розробляються роздільно. На відміну від цього, системний підхід припускає послідовний перехід від загального до приватного, коли в основі розгляду лежить мета, причому досліджуваний об'єкт виділяється 3 навколишнього середовища [3]. Саме за таким принципом доцільно проводити моделювання технологічних процесів збирання сільськогосподарських культур, що дозволить раціонально спланувати систему контролю як окремих елементів, так і технології в цілому.

При системному підході до моделювання систем необхідно перш за все чітко визначити мету моделювання. Поскільки неможливо повністю змоделювати реально функціонуючу систему (систему-оригінал, або першу систему), створюється модель (система-модель, або друга система) під поставлену проблему $[3,6]$. Таким чином, мета виникає 3 необхідних задач моде- лювання, що дає змогу підійти до вибору критерію й оцінити, які елементи ввійдуть до створюваної моделі.

Аналіз основних досліджень і публікацій, у яких започатковано розв'язання проблеми. Дослідженнями технологій збирання льонудовгунця в різні роки займалися такі науковці як Хайліс Г. А., Карпець І. П., Ковалев Н. Г., Ковалев М. М., Сидорчук О. В., Шейченко В. О., Рудніков М. В., Головій В. С., Гілязетдінов Р. Н., Макаєв В. І., Коропченко С. П. та інші $[1,2,4,5]$. Цими науковцями закладені основи теоретичного та практичного аналізу технологічних процесів збирання волокнистої культури за класичними технологіями та окреслені напрями для дослідження нових технологій збирання. До нових можна віднести технології, де запропоновано інші підходи до процесу збирання. Так, наприклад, замість брання пропонується застосовувати зрізування стебел льону, замість обертання згрібання і т. д. У Дослідній станції луб' яних культур Інституту сільського господарства Північного Сходу останніми роками активно ведуться пошуки оптимальної схеми збирання посівів льону довгунця в рамках нових технологій збирання. Запропоновані різні схеми збирання та підходи до вирішення тих або інших питань. Однак результати досліджень не в повній мірі систематизовані, що потребує додаткової уваги до аналізу одержаних даних. Саме цьому комплексу питань сьогодні варто надати особливої уваги, що допоможе визначитися 3 подальшим напрямом та об'ємом досліджень.

Мета досліджень: моделювання технологічного процесу збирання льону-довгунця 3 використанням машин загального призначення зводиться до вибору необхідних та достатніх операцій для його здійснення 3 визначенням взаємозв'язків між окремими елементами.

Завдання досліджень: визначення послідовності та необхідності операцій у збиранні льонудовгунця, що дозволить провести подальше регламентування технологій у загальній системі його вирощування. 
Результати досліджень. Для визначення етапів дослідження (рис. 1) застосований перехід від аналізу існуючих технологій збирання льону- довгунця 3 визначення найбільш проблемних ii елементів до подальшого пошуку варіантів залучення нових технологічних прийомів $[1,2]$.

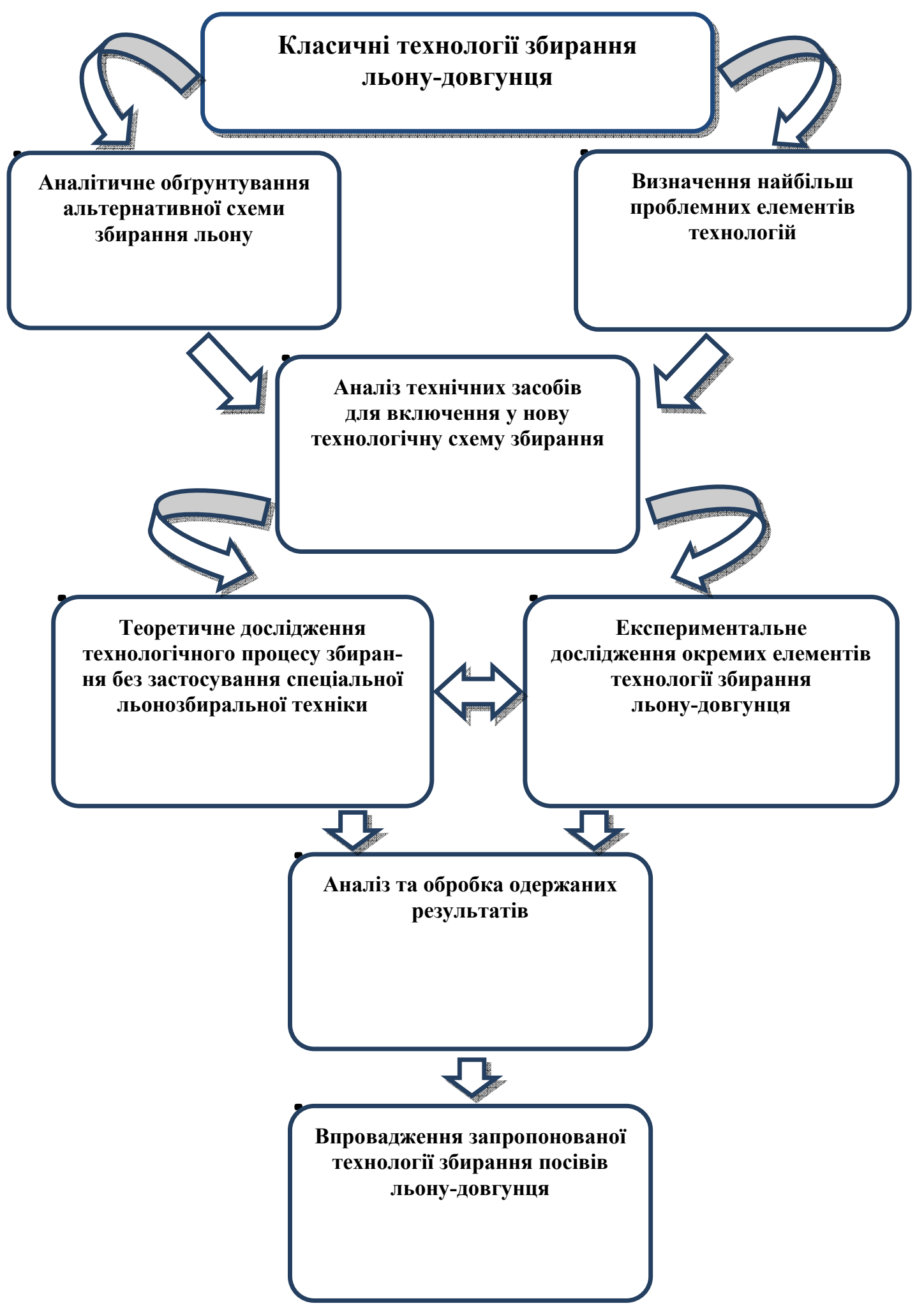

Рис. 1. Етапи дослідження технології збирання льону-довгунця 
Аналізуючи існуючі технології збирання льону-довгунця можна виділити найбільш проблемні їх елементи: низька продуктивність збиральної техніки та залежність від зовнішніх факторів (кліматичних умов, фізіологічних особливостей рослини тощо). Так низькопродуктивна операція брання льону може бути замінена на скошування із залученням відповідної техніки та технологічних прийомів. Для повноцінного дослідження можливостей залучення технічних засобів збирання в межах нової технології (збирання льону на коротке волокно) застосований алгоритм аналізу кожної окремої машини (рис. 2).

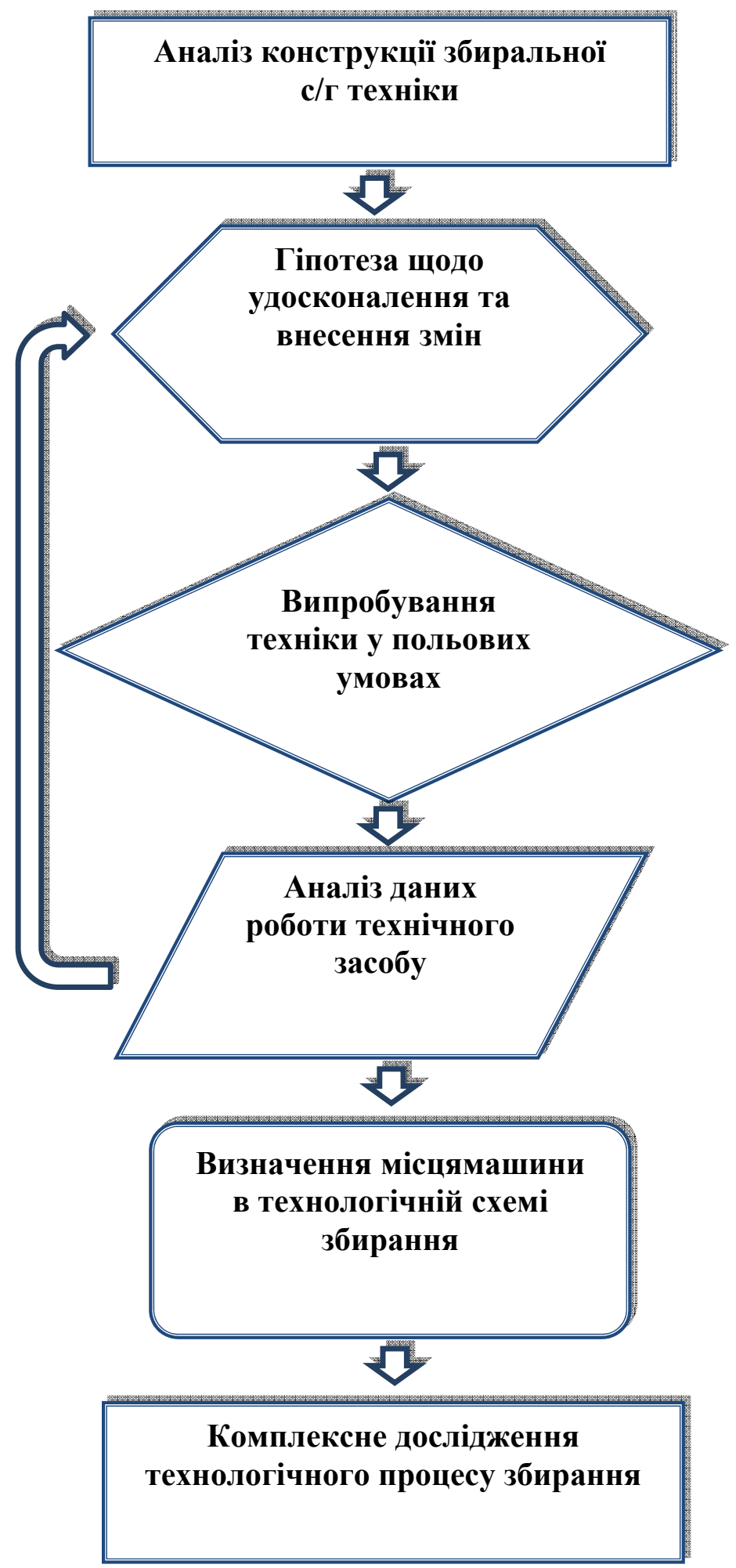

Рис. 2. Алгоритм визначення місця технічного засобу в технологічній схемі збирання 
Так, технологічний процес збирання посівів льону-довгунця на коротке волокно пропонується розпочинати 3 операції їх скошування (C) та укладання у валки (У) жниварками. Проаналізувавши робочий процес відомих жниварок та їх конструктивні особливості, ми прийшли до висновку, що найбільш прийнятною для скошування льону може бути жниварка типу ЖНР-4.

Робочий процес жниварки ЖНР-4 здійснюється наступним чином: під час роботи жниварки мотовило піднімає стебла рослин, підводить ï до ріжучого апарату і після зрізування вкладає скошені стебла на транспортер, котрий переміщує зрізану масу до центра жниварки. Через викидне вікно маса укладається на стерню, утворюючи валок. Для вибору оптимальних режимів роботи у залежності від стану культури передбачені регулювання мотовила за частотою обертання та виносу його по відношенню до ріжучого апарату. Жниварка ЖНР-4 на скошуванні льону-довгунця та укладанні у валок агрегатувалась 3 енергетичним засобом Е-302.

Наступним етапом у технологічному процесі збирання льону можна виділити природне просушування сформованих валків (В). Висушування льону у валках проводиться для дозрівання насіння, оскільки не всі насіннєві коробочки дозріли під час їх скошування. Висушування у валках дозволяє насінню дозрівати до 75-95\%. Втрати насіння не більше 3-5\%. Складові валків (стебла) повинні втратити вологість із $40 \%$ до $10 \%$.

Після просушування необхідним є обмолочування валків (О). Відомо, що льон-довгунець відноситься до легкообмолочуваних культур із дрібним плоским насінням. У зв'язку з цим (для запобігання подрібнення насіння та надмірного пошкодження лляної соломи) режим обмолоту повинен бути м'яким. Із занадто пошкоджених стебел льону волокниста частина відокремлюється від деревини, внаслідок чого деревина потрапляє в отвори на клавішах соломотрясу, не відриваючись від волокна, і створює складності для сепарування насіння, що призводить до втрат насіння на соломотрясі. Ці втрати досягають 10 і більше відсотків, що не відповідає агротехнічним вимогам комбайна. На соломотряс разом із соломою потрапляс від 15 до $20 \%$ насіння, не просепарованого у молотильному барабані. Показником незадовільного режиму обмолоту є наявність недомолоту, коли на 20-25 стебел можна знайти 2-5 необмолочених коробочок.
Основним чинником, що впливає на недомолот льону, вважається зазор між бичами молотильного барабану i підбарабанням, який вибирається за умови відсутності дроблення насіння. Частота обертання молотильного барабану для олійних культур не повинна перевищувати 500-600 хв ${ }^{-1}$. Проміжки між бичами барабану повинні бути закриті планкою. Нижне жалюзійне решето замінюється на пробивне 3 отворами діаметром 3,5 мм, підсівне решето 3 отворами 1,2 мм. Виходячи 3 основних вимог до обмолоту, вибирається зернозбиральна техніка та встановлюються відповідні режими роботи.

Після обмолочування валків зернозбиральним комбайном відбувається вилежування трести - іiі приготування. Стебла льону, які розстилаються у валок після виділення насіння зернозбиральним комбайном, частково руйнуються, але відокремлення волокна від деревини (що $\epsilon$ запорукою отримання якісного короткого волокна) практично не відбувається. Волокно відокремлюється від деревини тільки тоді, коли завершиться біологічне мочіння соломи і вона перетвориться на тресту.

На процес приготування трести впливають погодні умови, а саме: температура повітря та його відносна вологість. Найбільш сприятливою $€$ температура повітря $18-20{ }^{\circ} \mathrm{C}$ та відносна вологість повітря 60-80\%. Особливо дощова погода за даною температурою повітря прискорює процес приготування трести. Лляна солома, яка, на відмінну від традиційної технології одержання довгого волокна, знаходиться не на землі, а на стерні, контакту з землею практично не має. За цією умовою процес приготування трести проходить із значним відставанням від традиційної технології.

Нерівномірність розподілу стебел льону за довжиною валка $\epsilon$ основним фактором нерівномірного вилежування соломи. Тому для отримання якісної однорідної трести обов'язково потрібно проводити технологічні операції по розтягуванню згрупованих стебел за довжиною валка та їх перевертання або ворушіння (BB).

Ворушіння стебел у валках пропонується проводити ворушаркою ВЛ-3. Робочі органи ворушарки - зубчаті колеса - розпушують стебла льоносоломи таким чином, що більшість стебел 3 верхнього шару переміщувалися у нижній шар, а стебла лляної соломи 3 нижнього шару переміщувалися у верхній шар. Крім того, згруповані стебла за довжиною валка розтягуються, завдяки чому вони більш рівномірно розташовуються за довжиною валка. 
Інколи у валках маса скошеного льону становила менше 1 т/га. У зв'язку з цим за допомогою роторних граблів доцільно здійснювати операцію здвоювання валків трести (3). Встановлена ефективність застосування роторних грабель ГВР-6 для виконання операції зі здвоювання валків трести, що дозволяє підвищити продуктивність пресування трести у рулони прес-підбирачами та скороченню витрат пального 3 9,9 до 4,3 кг/га.

Підготувавши тресту до подальшого збирання, потрібно проводити підбирання та формування рулонів (ПФ). Підбирання лляної трести та формування iï у рулони рекомендується здійснювати рулонним прес-підбирачем ПРП-1,6 (або іншим лляним прес-підбирачем). Маючи ширину пресувальної камери 1,4 м преспідбирач повністю задовольняє виконання робочого процесу по формуванню лляної трести 3 валків у рулони. Рулони формувалися діаметром 1,3 м, довжиною 1,4 м, вага рулонів знаходилась у межах 210-220 кг. Продуктивність преспідбирача ПРП-1,6 на пресуванні здвоєних валків підвищується у два рази.

Навантаження рулонів (Н) на транспортні засоби пропонується здійснювати фронтальним навантажувачем ПФ-0,5 із пристроєм ППЛ-0,5, що навішується на трактори класу 14 кН. Конструкція пристрою ППЛ-0,5 дозволяє змінювати положення рулону в двох площинах, включаючи його нахил та поворот до $90^{\circ}$, що дозволяє в межах пристрою змінювати положення рулону 3 горизонтального в вертикальне i вкладати на транспортний засіб.

Для транспортування рулонів (Т) доцільно використовувати спеціальні платформи (типу ПП-12/3) або вантажні автомобілі таких марок як КАМАЗ, бажано з причепами із місткими кузовами. На автомобіль КАМАЗ рулони вкладаються у два ряди у вертикальному положенні, завдяки чому можна вкласти 28 рулонів льону, сформованих прес підбирачами, які мають довжину до 1,4 м, діаметром до 1,2 метра.

Водночас зі збиранням трести після операції обмолочування проводиться транспортування насіння від комбайна (ТH), очищення $(\mathrm{OH})$ та сортування насіннєвого матеріалу (CH). При очищенні вміст сміттєвих домішок не більше $0,2 \%$, вміст повноцінних зерен у відходах від маси зерна основної культури не повинен перевищувати більше $0,05 \%$. Після визначення необхідних операцій для здійснення процесу збирання льону-довгунця за новою технологією первинна модель складається 3 множини на- ступних операцій:

$\left\{\mathrm{O}_{\pi}\right\}: \mathrm{C}+\mathrm{Y}, \mathrm{B}, \mathrm{O}, \mathrm{TH}, \mathrm{OH}, \mathrm{CH}, \mathrm{BB}, 3, \Pi \Phi, \mathrm{H}, \mathrm{T}$,

де: $\left\{\mathrm{O}_{л}\right\}-$ множина технологічних операцій збирання льону-довгунця.

Основними та необхідними операціями є скошування (C) стебел льону з одночасним їх укладанням у валки, висушування (В) валків, обмолочування валків (О), транспортування насіння (ТН), операції очищення (OH) та сортування насіння (CH), операції підбирання валків та формування рулонів (ПФ), навантаження $(\mathrm{H})$ та транспортування (T) рулонів, а також операції очищення $(\mathrm{OH})$ та сортування насіння (CH). Операції ворушіння (BB) та здвоювання валків (3) не завжди є необхідними, оскільки залежать не лише від якості проведення попередніх операцій, а і від зовнішніх факторів у вигляді погодних умов, строків вилежування тощо. При цьому можна зазначити, що операції обмолочування (O) зумовлює подальші операції (TH), (OH) та $(\mathrm{CH})$, а операція підбирання та формування рулонів (ПФ) зумовлює операції $(\mathrm{H})$ та (Т), тобто ці операції $\epsilon$ залежними між собою. Аналізуючи проведені дослідження можна констатувати, що наслідкові операції також залежать і від зовнішніх факторів (кількісних та якісних характеристик сировини). Локалізування або відображення дії зовніш-нього середовища на строки та якість проведення включених операцій розглядалися вище при аналізі кожної операції. Слід також зазначити, що властивості льону, його вологість та інші характеристики не тільки впливають на можливість виконання збирального процесу, але зумовлюється i при цьому необхідність тих чи інших операцій взагалі. Слід зазначити, що управління технологічним процесом збирання льону проводиться безпосередньо по інформації про стан посівів льону, одержаної на час проведення збиральних робіт.

Висновок. Аналітичні дослідження технічних засобів для збирання таких прядивних культур як льон показали, що поруч із класичними технологіями збирання даних культур на довге волокно проходить розвиток нових технологій із застосуванням сільськогосподарської техніки загального призначення, метою яких є одержання насіння та короткого волокна як основного продукту. Моделювання технологічного процесу збирання льонудовгунця дозволяє визначити необхідні та допоміжні операції, встановити взаємозв'язки між ними та окреслити їх зв'язок із зовнішнім середовищем. Проведені дослідження показали, що техніка, яка пропонується для здійснення операцій збирання, може бути замінена аналогічною, але після додаткового i дослідження в тих чи інших виробничих умовах. 


\section{БІБЛІОГРАФІЯ}

1. Макаєв В.I. Традиційні та перспективні напрямки механізації льонарства України / Макаєв В. І. // Проблемы легкой и текстильной промышленности Украины. - 2010. - №1(16). C. 92-95.

2. Макаєв В. I. Удосконалення роздільного способу збирання льону-довгунця 3 метою поліпшення якості продукції // Межвузовский журнал «Проблемы легкой и текстильной промышленности Украины». - Херсон, 2004. - №1(8). C. $96-100$.

3. Советов Б. Я. Моделирование систем: Учеб. для вузов. - 3-е изд. - М. : Высшая школа,

2001. $-343 \mathrm{c}$.

4. Хайлис Г. А. Механика растительных материалов / Хайлис Г. А. - К. : УААН, 2002. - 374 с. (Изд. второе, переработаное и дополненое).

5. Хайлис Г. А. Основы теории и расчета сельскохозяйственных машин / Хайлис Г. А. - К. : Изд-во УСХА, 1992. - $240 \mathrm{c.}$

6. Швайко В. М., Соломка В. О., Соломка О. В. Особливості побудови математичних моделей процесів сільськогосподарського виробництва // Сільськогосподарські машини. - Зб. наук. ст., Вип. 13. - Луцьк: Ред.-вид. відділ ЛДТУ, 2005. $285 \mathrm{c}$. 